\title{
International Law Non-Compliance: Assessing Uruguay's Decision to Legalize Cannabis under Jose Mujica Regime
}

\author{
Novia Sinta Tesalonika, Natasya Kusumawardani \\ School of International Relations \\ President University, Indonesia \\ natasya.kusumawardani@president.ac.id
}

\begin{abstract}
Abstrak
Uruguay telah meratifikasi konvensi pengendalian narkoba internasional yang terdiri dari Single Convention on Narcotic Drugs 1961, yang diamandemen 1972 Protocol, Convention on Psychotropic Substance 1971, dan United Nations Convention against Illicit Traffic in Narcotic Drugs and Psychotropic Substances 1988. Semenjak itu, pemerintah Uruguay sudah mengambil bagian dalam Perang Melawan Narkoba. Pada tahun 2012, Jose Mujica mengusulkan kebijakan legalisasi mariyuana. Draf kebijakan tersebut kemudian diundangkan dalam Law no. 19172 yang melegalkan dan meregulasi penanaman, konsumsi, dan penjualan mariyuana pada 20 Desember 2013. Peraturan perundangan-undangan ini melanggar konvensi pengaturan narkoba internasional dan dikritik oleh International Narcotics Control Board (INCB) yang merupakan badan PBB United Nations Office on Drugs and Crime (UNODC). Meskipun dikritik, pemerintah Uruguay tetap menentang norma dari konvensi. Makalah ini menganalisis faktor kausatif dari perubahan perilaku ini. Meningkatnya pengguna narkoba menyebabkan banyak masalah di Uruguay, terutama peningkatan aktivitas kriminal, yang menyebabkan masalah nasional dan menghambat upaya pemerintah melawan perdagangan narkoba gelap dan meningkatkan keamanan masyarakat. Hal ini menjadi ancaman terhadap kepentingan nasional. Karenanya, pemerintah memercayai bahwa tunduk pada konvensi tidak akan membantu mereka mengamankan diri dari ancaman ini. Studi kasus ini menunjukkan bahwa perilaku negara terhadap hukum internasional akan berubah sesuai dengan perubahan kepentingan nasional.
\end{abstract}

Kata kunci: narkotika, Uruguay, ketidakpatuhan, legalisasi mariyuana, perdagangan narkotika, hukum internasional

\begin{abstract}
Uruguay has ratified the international drug control conventions that consist of Single Convention on narcotic drugs 1961 as amended 1972 protocol, the convention on psychotropic substance 1971, and United Nations Convention against Illicit Traffic in Narcotic Drugs and Psychotropic Substances 1988. Since then, the Uruguayan government has been a part of the "War on Drugs" campaign. In 2012, Jose Mujica proposed the policy of cannabis legalisation. The proposal was signed and passed into Uruguay law no 19172 that allow and regulate the
\end{abstract}


plant, consumption and sale of cannabis on December 20th, 2013. This policy has violated international drug control conventions and received critics from the International Narcotics Control Board (INCB), the body of the United Nations Office on Drugs and Crime (UNODC). Despite the critics from INCB, the government stood against the norm of the treaty. This article analyses the causative factors that trigger this behavioural change. The increasing number of drugs users caused many problems in Uruguay especially the increasing numbers of criminal acts. It created national problems and hampering the government's efforts to fight drug trafficking and ensuring the safety of society. By all mean, it became threats to their national interest. Thus, the government believed that compliance with the conventions could not help them to overcome these threats. Uruguay case has shown that state behaviour towards international law will change along its changing national interest.

Key Words: drugs and narcotics, Uruguay, non-compliance, cannabis legalization, narcotics trafficking

\section{Background}

In this globalisation era, one of the biggest and lucrative markets is the drug market. To manage the use and distribution of Narcotics, in 1961, UNODC formed a convention dealing with narcotics and psychotropic, known as "Single Convention on Narcotic Drugs 1961" which regulated the type, how to control, and the measurement against narcotics. Then in 1972, there was a renewal of the convention, which later resulted in the Single Convention on Narcotic Drugs, 1961 amended by Protocol 1972 (Bewley-Taylor, D., \& Jelsma, M., 2012). Besides, there is a Convention on Psychotropic Substances 1971 that focused on the manufacture of non-state agricultural drugs (Panicker, B., 2015). In 1988, UNODC had another convention to regulate and to combat drug trafficking by the United Nations Convention against Illicit Traffic in Narcotic Drugs and Psychotropic Substances 1988 (Panicker, B., 2015). In order to organise and monitor the implementation of International Drug Control Conventions, in 1968 UNODC established the International Narcotics Control Board (INCB) (Marcos.santos., n.d). In principle, INCB uses the conventions to monitor and limit the use of cannabis as a treatment and science, as well as ensure international cooperation in the control of these narcotics.

Uruguay is one of the countries that ratified the International Drug Control Conventions and supported War on Drugs declared by the United States in 1971 even though in the implementation, Uruguay maintained a relatively liberal attitude toward drugs consumption (A Brief History of the Drug War., n.d; Transform Drug Policy Foundation., n.d.). "War on drugs" is a phrase used by governments to stop the use, distribution and illegal trafficking of drugs by increasing and enforcing penalties for offenders (Transform Drug Policy Foundation., n.d.). However, on 20th December 2013, under the administration of Jose Mujica, Uruguay violated the provision of International Drug Control 
Conventions by becoming the first country in the world that fully legalized cannabis by having Uruguay Law No. 19172 that regulates cannabis possession, growth, and distribution of the plant (Boidi, M. F., Cruz, J. M., Queirolo, R., \& Bello-Pardo, E., 2014). According to the statement of Jose Mujica, he argued that the real problem was not consuming cannabis itself, but illegal drug trafficking.

"Consumption of cannabis is not the most worrying thing, drug-dealing is the real problem" ... "We had 80 deaths from drug-related violence last year, and only 3 or 4 deaths from drug overdoses, ... So, what is worse: drug trafficking, or drug consumption? ... And the advantage of Uruguay's legalization policy is that we can identify who is consuming. If we identify consumers, we can help them. If we criminalize them and keep them underground, we steer them towards drug dealers and wash our hands of responsibility He argued that the U.S. should relax its war on drugs and "give a hand" to Latin American countries that are trying to legalize some drugs, in order to reduce fighting between criminal groups." (Hernandez, V., 2012; News, A., 2013)

The policy of Uruguayan government became a contradiction to the International Drug Control Conventions and criticised from the International Narcotics Control Board (INCB). However, even if the Uruguayan government were criticised by the INCB, they kept pursuing the policy. The article will employ Realist theory to analyse the changes in state behaviour towards the international drugs regime. Realist theory will help to explore the factors that considered as threats and security problems to Uruguay's national interest in Jose Mujica administration.

\section{Compliance to International Law in Realist Perspective}

International law is defined as "a body of principles, duties, and rules that effectively manage the obligations of sovereign states in the international system for their mutual relations" (Brunnée, Jutta, and Stephen J. Toope., 2010). Convention as one of the sources of international law is a multilateral international agreement that involves many parties to formulate legal principles for the international community that is not officially formed until there are two or more states that consent to be bound by the points under the treaty (United Nations.,1969). The most frequent actions by the state towards conventions are signature and ratification (Malanczuk, P., \& Akehurst, M., 1997). According to Vienna Convention 1969 Article 12 (1) about the consent to be bound by signature and Article 14 (1) about the consent to be bound by ratification (United Nations.,1969). By expressing consent to be bound by signature means that the states accept the content of international law provision; whereas, by express, the consent to be bound by ratifications means that states must implement the content of international law into their national law (United Nations.,1969). However, states might not always be willing to comply with international law. This condition has sparked the never-ending debate of the compliance theory to international law. 
One of the theories that explain this debate is realism. In seeing international law, most of the international relations scholars of realism perspective tend to be sceptical. Realism assumes that under the condition of international anarchy, 'a state will comply with international law only when compliance is in the state's selfinterest' (Burgstaller, 2005). The state is the main actor in the international system while the other actors are categorised as minor actors with slight power and interest in international politics such as the International Law. Therefore, states which are driven by the state interest and sovereignty (W. Julian KorabKarpowicz., 2010; Shirley V. Scott., 1994) will undermine international law when it cannot serve their interests. According to Realists, to obey and follow international law often implies that states must have converging interests with the law. Realists also believe that state interest in international relations could be hardly achieved through international law (Oliver, J., 2016; Aron, Raymond., 1981). Morgenthau saw international law as ultimately impotent (Shirley V. Scott., 1994). Morgenthau argued that international law has several deficiencies, the crucial one being the decentralised character as a result of the decentralised structure of international society. This character has made international law unable to agree on legal rules because of the divergent interests of states. Even though they achieve agreement, insecurity and confusion frequently reign. Consequently, states tend to evade international legal rules which might be harmful to them and treated international law as a tool to furthering their ends (Morgenthau H. J., 1993, pp. 296-299).

Based on Morgenthau's analysis on how national interest contributes significantly on American foreign policy instead of moral principles in dealing with other nations, Kiyono argued the concept of national interest could be seen in the two points in the US constitution, namely general welfare and due process clauses (Kiyono, K., 1969). Due process clauses are related to the duty of a state as a nation which are self-preservation and generating welfare. Regarding selfpreservation, Morgenthau has stated that "survival" is the main and only concern of the states. In the end, states will strive for their survival instead of moral principles. Meanwhile, general welfare is derived from the idea that the state must provide welfare for its future generations now and then carries greater magnitude compared to moral principles (Morgenthau H. J., 1949, pp. 208). Thus, these arguments led Kiyono to conclude that there are two factors relating to national interest, the first one is "rationally demanded and therefore, of necessity and the second factor are changeable and decided by the situation" (Kiyono, K., 1969). This article will focus on 'the factors of national interest' of Morgenthau because based on the above assessment on Morgenthau's argument, the changing of interest in one state will impact to their compliance of international law.

\section{Cannabis Legalization in Uruguay Under Jose Mujica Administration}

The debate about cannabis legalisation is not new, but the significant movement took place under the administration of Jose Mujica in 2010-2015 (Pascual, A., 
2014). The first bill to allow home cultivation for personal use was proposed by Luis Lacalle Pou (member of Partido Blanco/Nacionalto) in November 2010 (Hetzer, H., \& Walsh, J., 2014). However, then, the proposal was not accepted (Transnational Institute., 2003). On December 2010, the bill was proposed again by Nicolás Núñez (member of Socialist Party), Fernando Amado (member of Partido Colorado), and Sebastian Sabini (member of Movimiento de Participación Popular) but still, the proposal was rejected (Transnational Institute., 2014).

In 2011, the same bill to legalise home cultivation cannabis in Uruguay was drafted to the Congress. It happened because there were massive social movement and public protests to support the case of Alicia Castilla. The public protest was a demand to release Alicia, who was arrested for home cultivating and had 29 cannabis plants in her garden in February (Washington Office on Latin America (WOLA), Transnational Institute (TNI), \& Open Society Foundation (OSF)., 2012). She planted cannabis for her personal use to help her having a better sleep and for her research since she was writing a book about cannabis (Goñi, U., 2017). Then, she was imprisoned for 95 days because, at that time, drug consumption for personal use in Uruguay was not illegal but cultivation was prohibited (Goñi, U., 2017). Then, in March 2011, the legislator among parties negotiates to unify the proposal about the previous bill regarding cannabis legalisation (Pascual, A., 2014). In May 2011, Alicia Castilla was released, and the draft was submitted to the Congress (Transnational Institute., 2014).

In June 2012, Uruguayan President Jose Mujica published a document known as "Strategy for Life and Coexistence" which includes 15 points of proposed regulations to address insecurity in the country. Point no. 7 is about legalising and controlling cannabis sales as well as state production of the drugs, Uruguay was planning to create state monopoly in cannabis production and distribution (Walsh, J., \& Ramsey, G., 2016). After the debate, the bill was passed in the house of representative on July 31,2013 , and then submitted to Mujica for ratification that known as Law No. 19172 or Ley no 19172 Marihuana Y Sus Derivados on December 20th, 2013 then was applied on 24 December 2013 (Transnational Institute.,2014; Republica Oriental Del Uruguay Poder Legislativo., 2013; Ramsey, G., 2016).

The decision of the Uruguayan government to legalise cannabis was supported by Pro Derechos that led the campaign called Regulaćions Responsable or Responsible Regulations that helped by the Drugs Policy Alliance (DPA) . The campaign explained that cannabis regulation could give several advantages, e.g. it could strengthen public safety by limiting and separating the cannabis users from other more dangerous drugs substance; it will improve public health because the regulation is under government quality control; the benefit and tax revenue of cannabis sales can be used to invest in developing education for the prevention and cannabis user treatment; and, it could undertake the legal contradiction of cannabis distribution and consumption. 
In 2013, the proposal of government legalising and controlling cannabis or regulation bill about cannabis was approved and had been signed into the law no. 19172. The cannabis policy reform is called Estrategia por la vida y la convivencia or Marijuana and its derivatives that include the regulation of cannabis use and market in Uruguay (Moreno, R. P., n.d.).

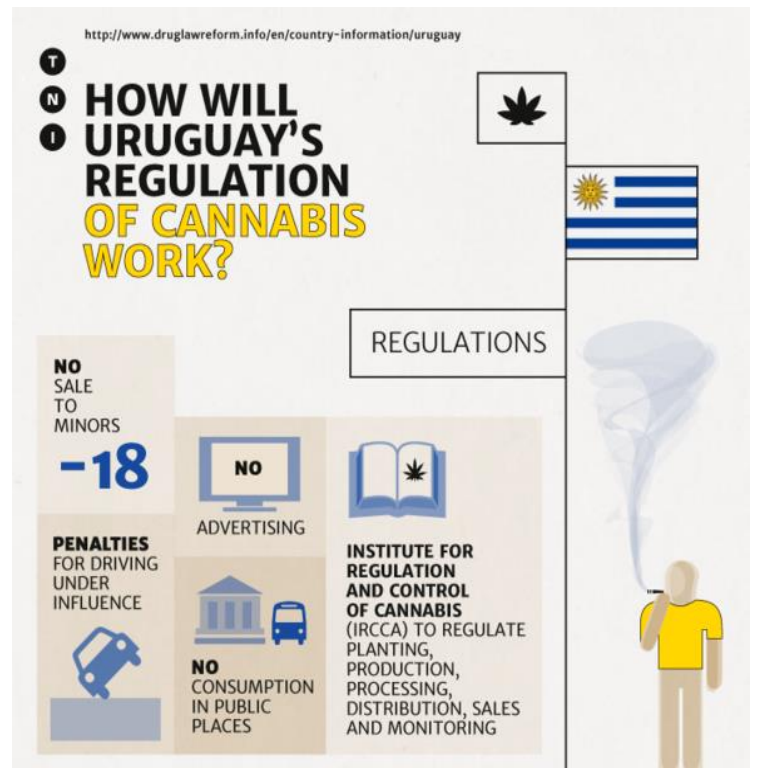

Pict. 1 The system of Uruguay cannabis regulations (Transnational Institute)

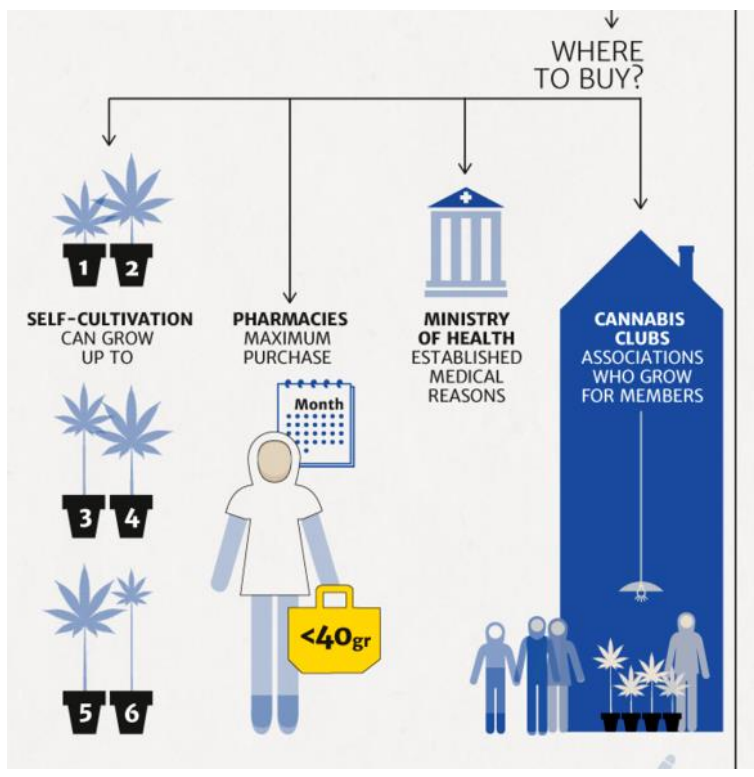

Pict. 2 Three legal access to cannabis (Transnational Institute)

The implementation of cannabis legalisation in Law No. 19172 was controlled and monitored by the Institute of Regulation and Control of Cannabis (IRCCA). Even though the government allows the use of cannabis, there are several regulations from the government including the users must be Uruguayan or permanent residents over 18 years old and have to register to IRCCA; and consuming cannabis in public places and driving under the influence of cannabis and advertisement is prohibited (Ramsey, G., \& Walsh, J., 2017). There are three legal methods to access and obtain cannabis in Uruguay. The first method is Home Cultivation, and this method allows the users to grow up to six cannabis plants per household for their consumption with the total for annual production of the drug must not exceed 480 grams or 40 grams per month (Ramsey, G., 2016). The second method is Cannabis club that can have minimum 15 members and maximum 45 members to collectively grow the cannabis up to 99 plants in the same place, but prohibit to have more than $480 \mathrm{grams}$ each member per year (Ramsey, G., 2016). The last method is buying in pharmacies. Individuals can purchase cannabis with or without the prescription up to 40 grams of the drug per month (10 grams per week) in licensed pharmacies (Ramsey, G., 2016). 


\section{The Factors that Lead to Cannabis Legalization}

Several factors make the Uruguayan government consider legalising cannabis. The factors are considered as threats to their national security and interests. Those factors are the increased crime rate, health, and economic sector that was supported by the statement of Jose Mujica,

"Marijuana legalization began essentially as a security issue... We have spent many years repressing and spending money to fight drug trafficking... we have had glorious successes, but trafficking continues to increase. In other words, this policy has failed for many decades. And it's common sense that if you want to change you cannot keep on doing the same thing: You have to try other ways... We are proposing a market logic, if we can't beat them through policing, we are going to try to steal the market from them so that this ceases to be a business" (Planas, R., 2014)

Mujica highlighted that the policy to fight drug trafficking has failed. Instead, it resulted in greater security problems. Meanwhile, without eliminating the threats to national security, Uruguay cannot protect its national interest. In this context, this article will analyse several factors which contribute to what Mujica perceive as threats to their national security. In which, in the end, it has led them to disregard international drugs regime that has been ratified and implemented before Mujica period.

\section{The Increased Crime Rate}

Uruguay was one of the safest countries in South America. However, then, the number of crime rate increased and became a threat to public security. The increasing crime rate was related to drugs trafficking (Ramsey, G., 2013). The number of criminals increased from year to year especially for the case of robbery, and homicide rose significantly in 2012 as shown in picture 3.

Homicide

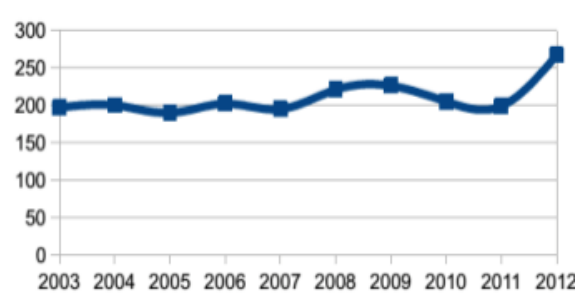

Robbery

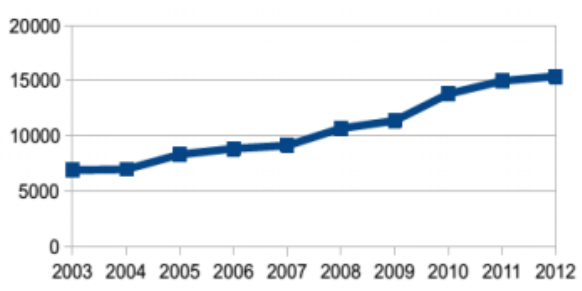

Pict. 3 Homicides and Robbery (Ministry of Interior Uruguay - Ministerio del Interior., 2012).

The conflicts and problems drove the crimes related to drugs among local groups (ISSAT., 2015). One of the main factors of conflicts is the competition among the 
local groups to gain more significant share of the local drug market (ISSAT., 2015). Jose Mujica statement about crimes related to drugs,

"... They follow the path to crime because they don't have the money... they become dealers because they have no other financial means to satisfy their vice." ... Consumption of cannabis is not the most worrying thing, drugdealing is the real problem ... We had 80 deaths from drug-related violence last year, and only 3 or 4 deaths from drug overdoses,... So what is worse: drug trafficking, or drug consumption? (Cave, D., 2012; Hernandez, V., 2012; News, A., 2013)

According to the statement, one of the concerns is the number of deaths caused by drugs-related violence, which includes drug trafficking. It is higher than the number of deaths caused by drugs overdose (News, A., 2013). Besides, drug trafficking is the main factor of security issue because it was identically and related to violence such as homicide and robbery as well as the violence among international drug cartel operation (Hetzer, H., 2013; Thoumi, F. E., n.d.). The number was increasing up to 100 per cent from 2003-2012, with a higher number in 2012. In 2006 there were 9,669 cases, and in 2012 there were 15.414 cases. While the trend of murder has increased relatively high, in 2005, there were 188 cases, and in 2012 there were 267 cases (Ministry of Interior Uruguay - Ministerio del Interior., 2012).

This security issue led Uruguay to the perception of insecurity (ISSAT., 2015). The problem of insecurity faced by Uruguay is related to the illegal drugs trade that primarily caused by the violence in international drug cartel that manages the black market with a high price (Londoño, E., 2017). In order to overcome the issue, the Uruguayan government, in particular, the Ministry of Interior, gave more attention to various law enforcement efforts including drug abuse and trafficking, which eventually resulted in a large number of prisoners and the state budget (Garibotto, G., n.d.). The national interest of the country regarding the issue of security is to decrease the number of crimes related to drugs by taking over the market of illegal drugs trafficking.

Uruguayan government's response to overcome the problem of insecurity is to set up a new model of the law on cannabis which allows planting, using and selling cannabis with the following rules and restriction by IRCCA institutions under the Law no. 19,172 (Moreno, R. P., n.d.; Transform Drug Policy Foundation., 2017). According to the law, the people are allowed to plant their cannabis adjusted with the regulations from IRCCA as it is intended for citizens who do not have the money to buy marijuana in licensed pharmacies, so they can also consume marijuana. Under these regulations, cannabis users do not need to commit criminal acts like robbing, killing and involving in drugs trafficking in the black market to get cannabis. Every Uruguayan registered in IRCCA is allowed to grow 
cannabis for consumption, or they can easily buy marijuana in the licensed pharmacies. (Queirolo, R., Boidi, M. F., \& Cruz, J. M., 2016 ; Goñi, U., 2016)

Uruguayan government's response to overcome the problem of insecurity is to set up a new model of the law on cannabis which allows planting, using and selling cannabis with the following rules and restriction by IRCCA institutions under the Law no. 19,172 (Moreno, R. P., n.d.; Transform Drug Policy Foundation., 2017). According to the law, the people are allowed to plant their own cannabis adjusted with the regulations from IRCCA as it is intended for citizens who do not have the money to buy marijuana in licensed pharmacies, so they can also consume marijuana. Under these regulations, cannabis users do not need to commit criminal acts like robbing, killing and involving in drugs trafficking in black market to get cannabis. Every Uruguayan registered in IRCCA is allowed to grow cannabis for consumption or they can easily buy marijuana in the licensed pharmacies. (Queirolo, R., Boidi, M. F., \& Cruz, J. M., 2016 ; Goñi, U., 2016)

\section{Public Health Problems}

The high use of marijuana and cocaine paste became one of the government considerations in legalising cannabis (Halter, C., 2016). Based on the table, the highest number of drugs operation recorded is Marijuana with 1,574 operations and the second highest is cocaine paste with 979 operations (Garibotto, G., n.d).

\begin{tabular}{|l|l|l|}
\hline \multicolumn{3}{|l|}{ Marijuana } \\
\hline Grams & Operations & Percentage \\
\hline 0 to 9 & 681 & 43.3 \\
\hline 10 to 49 & 434 & 27.6 \\
\hline 50 to 99 & 118 & 7.5 \\
\hline 100 to 499 & 156 & 9.9 \\
\hline 500 to 999 & 60 & 3.8 \\
\hline 1,000 to 1,999 & 77 & 4.9 \\
\hline 2,000 to 2,999 & 19 & 1.2 \\
\hline 3,000 to 3,999 & 10 & 0.6 \\
\hline 4,000 to 4,999 & 6 & 0.4 \\
\hline 5,000 to 9,999 & 13 & 0.8 \\
\hline Total & 1,574 & 100.0 \\
\hline
\end{tabular}

\begin{tabular}{|l|l|l|}
\hline \multicolumn{3}{|l|}{ Cocaine (salts) } \\
\hline Grams & Operations & Percentage \\
\hline 0 to 9 & 176 & 35.3 \\
\hline 10 to 49 & 87 & 17.4 \\
\hline 50 to 99 & 28 & 5.6 \\
\hline 100 to 499 & 43 & 8.6 \\
\hline 500 to 999 & 28 & 5.6 \\
\hline 1,000 to 1,999 & 53 & 10.6 \\
\hline 2,000 to 2,999 & 31 & 6.2 \\
\hline 3,000 to 3,999 & 30 & 6.0 \\
\hline 4,000 to 4,999 & 9 & 1.8 \\
\hline 5,000 to 9,999 & 14 & 2.8 \\
\hline Total & 499 & 100.0 \\
\hline
\end{tabular}

\begin{tabular}{|c|c|c|}
\hline \multicolumn{3}{|c|}{ Cocaine paste } \\
\hline Grams & Operations & Percentage \\
\hline 0 to 9 & 540 & 55.2 \\
\hline 10 to 49 & 276 & 28.2 \\
\hline 50 to 99 & 30 & 3.1 \\
\hline 100 to 499 & 43 & 4.4 \\
\hline 500 to 999 & 16 & 1.6 \\
\hline 1,000 to 1,999 & 45 & 4.6 \\
\hline 2,000 to 2,999 & 9 & 0.9 \\
\hline 3,000 to 3,999 & 8 & 0.8 \\
\hline 4,000 to 4,999 & 1 & 0.1 \\
\hline 5,000 to 9,999 & 11 & 1.1 \\
\hline Total & 979 & 100.0 \\
\hline
\end{tabular}

\begin{tabular}{|l|l|l|}
\hline Cannabis plant & \multicolumn{3}{l|}{} \\
\hline Unidades & Operations & Percentage \\
\hline 0 to 9 & 63 & 87.5 \\
\hline 10 to 49 & 8 & 11.1 \\
\hline 50 to 99 & 1 & 1.4 \\
\hline Total & 72 & 100.0 \\
\hline
\end{tabular}

\begin{tabular}{|l|l|l|}
\hline MDMA (ecstasy) & \multicolumn{3}{|l|}{} \\
\hline Unidades & Operations & Percentage \\
\hline 10 to 49 & 4 & 57.1 \\
\hline 100 to 499 & 2 & 28.6 \\
\hline 1,000 to 1.999 & 1 & 14.3 \\
\hline Total & 7 & 100.0 \\
\hline
\end{tabular}

\begin{tabular}{|l|l|l|}
\hline Coca leaf & \multicolumn{3}{|l|}{} \\
\hline Grams & Operations & Percentage \\
\hline 100 to 499 & 4 & 40.0 \\
\hline 500 to 999 & 3 & 30.0 \\
\hline 1,000 to 1,999 & 3 & 30.0 \\
\hline Total & 10 & 100.0 \\
\hline
\end{tabular}

Table 1.Transnational Institute: Operations of Drugs in Uruguay in 2012 (Garibotto, G., n.d.)

The high numbers of marijuana users who cannot buy it due to its high price or unavailability have moved to the second option which is cocaine paste. It is also highlighted by the Minister of the Interior in Uruguay, Eduarto Bonomi; he stated that "The largest market for drugs in Uruguay is marijuana. However, to get it, people have to access the illegal market - the places where pasta base is sold. If 
someone goes to get cannabis and there is not any, they can end up buying pasta base instead"(Pressly, L., 2014). Cocaine pasta, categorised as a hard drug also known as pasta base (Paco), is a product of raw coca leaf that processes into refining cocaine (Hurtado-Gumucio, J., 2000; Transnational Institute., 2006). Paco is sold in the black market cheaply, but the effect of consuming Paco is more dangerous and stronger than any other drugs (Hurtado-Gumucio, J., 2000). A third of more than 8,500 prisoners said that they were under the influence of alcohol or drugs when committed crimes and nearly half of those had consumed pasta base, they are often associated with theft and robbery (Pressly, L., 2014). In addition, the attempts of suicide were also found to be more common among pasta base (Paco) shortly after using. (Pascale, Hynes, Cumsille, \& Bares, n.d)

In order to reduce the number of Paco users, the government considered legalizing the use of marijuana so that the Paco users can move to cannabis. Besides, cannabis can also be used as the treatment for the Paco users to relieve pain during the hallucinating moment (Pressly, L., 2014). It was supported by the statement of the country's undersecretary for public health, Leonel Briozzo that said "Cannabis is new strategies for drug addiction treatment, especially for harder drugs like 'pasta base. Moreover, in that sense, we harbour a possible hope that medical marijuana can play a role in this as well" (Sledge, M., 2014). It does not mean that the government proposes an idea to use cannabis as the substitute for dangerous drugs, but the idea is to use cannabis to help to treat the Paco users and help any other diseases (Madras, B. K., n.d.).

By legalising cannabis, Uruguay is going to treat the prison inmates that addicted to any other drugs especially pasta base (Sledge, M., 2014). Fact is, cannabis has a long history in medical purpose as long as it is consumed in the right and proper dose (Madras, B. K., n.d.). Cannabis can be used to relieve and reduce pain, treat anxiety, palliative care, and even it can help to prevent the spread of cancer (Madras, B. K., n.d.). Besides, the legally marketed cannabis in Uruguay is ultralight cannabis with an addictive rate four times lower than the type of cannabis sold on the black market with a lower price than in the black market (Holmes, S., 2017; Uruguay pharmacies start selling cannabis straight to consumers., 2017). Therefore, it is in the interest of the Uruguayan government to legalise cannabis in order to improve and ensure public health (Transform Drug Policy Foundation., 2017).

Legalising cannabis as one of the solutions of the public health problem in Uruguay did not go without criticism. The president of INCB, Raymond Yans International Narcotic Control Board (INCB), was concerned about the impact of cannabis legalisation in the health sector. INCB assumed Uruguay has failed in considering the impact and consequences of using cannabis for the public health that could not protect the young people and could trigger the lower age of cannabis first use (INCB., 2013). 
In response to the critics, Jose Mujica stated, "We (the government) have to guarantee that all of our users are going to be able to get a quality product" (Cave, D., 2012). Following this statement, the Uruguayan government has regulated the system under Uruguay law no. 19172 in Chapter II about Health of the General Public and Drug Users in article 9, the government has managed the National Integrated Health System to prevent the problem of cannabis use and to promote the public health (Uruguay Law no. 19172 Article 9). Then in article 10, the government has managed the National Public Education System to educate the public about the risk and problematic of using cannabis (Uruguay Law no. 19172 Article 10). Other than National Integrated Health System and National Public Education System, Uruguayan government also has the Institute for the Regulation and Control of Cannabis (IRCCA) that established to administer licenses to the market and cannabis users by controlling the quality and dose of the cannabis as well as managing the user's data (Ramsey, G., 2016; Uruguay Law no. 19172 Article 18).

\section{Economy: Reducing National Budget Costs and the Profit of Marijuana Sales}

The regulation that prohibits the use and sales of cannabis has raised a lot of emerging problems in Uruguay such as a lot of cases about the use of marijuana that people were arrested in possession of less than $10 \mathrm{~g}$ (Transnational Institute., n.d) that caused the increase of inmates while Uruguay has limited inmate cell capacity (Garibotto, G., n.d). In order to overcome the problem, the government of Uruguay needs to increase its national budget that led the country to financial losses. The financial losses have made the government of Uruguay reconsider the prohibition of cannabis. In dealing with the problem, the Government of Uruguay has to increase Uruguay's Domestic Budget as a source of funds to increase the number of prisons and strengthen the prison system (Garibotto, G., n.d). Regarding the national budget costs, according to the data of Junta Nacional de Drogas (JND), the large number of illegal cannabis that entered the territory of Uruguay, in 2011 to 2013 caused Uruguay to suffer financial losses. In 2011 Uruguay experienced a loss of $45,876,740$ pesos, in 2012 as much as $46,344,870$ pesos and in 2013 as much as 46,578,935 pesos. The total of Uruguay loss in 2011-2013 is $138,800,545$ pesos or about 6 million US\$ (Infodogras., n.d.). Financial losses made the government consider cannabis regulations by legalising it. The loss was the result of government efforts to imprison the users by adding infrastructure by adding new prisons due to a large number of inmates associated with marijuana cases (Garibotto, G., n.d.). Also, not only increase the number and capacity of prisons, but the government also has to spend more money to support prisoners in prisons and the costs of rehabilitating cannabis users with problems with professionals (Garibotto, G., n.d.). Other than reducing the national budget to tackle drugs users and trafficking, by legalising cannabis Uruguay government is also able to take over the cannabis market from the black market and illegal drugs trafficking (Euronews., 2018). 
Under Law no. 19172, Uruguay can reduce their budget to overcome the problem and crime caused by drugs as well as gain profit from the tax revenue (Watts, J., 2013). According to Uruguay Law no. 19172, the legalisation of cannabis makes the government as the "drug-dealer" for the country; it means that the tax revenue from cannabis sales profit became the state income that can be used to build and develop the country. In the subject of legalising cannabis in Uruguay, private parties such as companies that have received permission from the IRCCA are required to pay taxes to the state in the management of growing marijuana. Tax revenue from private parties can be used by the government to cover government losses and socialise to schools and communities about the impact of cannabis use.

According to Secretary of the National Medicines Council, Julio Calzada as president of IRCCA stated that cannabis consumption is estimated at 18-25 tons per year in Uruguay (Walsh, J., \& Ramsey, G., 2016). From these estimations, there is a demand of 25 tons of cannabis per year. Meanwhile, the cost of cannabis production in Uruguay is US $\$ 0.85$ - 1 per gram (Goni, U., 2013). Then the transactions that have occurred in Uruguay related to cannabis sales can reach about US \$ 21.25 million - 25 million. With that in mind, it will be beneficial for the state coming from the cannabis tax. Calzada concluded that about 70,000 monthly users of the country could earn around 6 million USD (Cave, D., 2012). The calculation was used to support the interest of Uruguay to reduce the national budget and gain the profit of tax revenue from the sales of cannabis.

\section{National Interest vs International Law}

The national interests of Uruguay, as explained above, consist of several factors which are to decrease the high rate of crime related to drugs; to improve and to ensure the betterment of public health system; and to reduce the national budget which previously has been used to overcome the drugs related problems; and to gain the profit from the sales of cannabis that can be used for the state development. These interests influenced the decision of Uruguay to act towards the international drug control conventions. International drug conventions could not help the government to solve those problems and hampered the achievement of national interests. Thus, international drug control conventions have failed to solve the state's problems. Uruguay then decided to not comply to the drug convention under the idea of sovereignty to adopt its national policy and disregarded international critics in order to protect their national interest (Oliver, J., 2016). The practical way according to Uruguayan government is the legalisation of cannabis (Panicker, B., 2015).

According to Morgenthau, there are two factors that influence the idea of national interest, the first is demand and necessity, in this case the demand and necessity is the high number of drugs operations especially the number of cannabis operation that known as the highest number in drugs operations in 2012 (Kiyono, K., 1969; Garibotto, G., n.d.). Besides, the demands also come from Uruguayans 
that support the government to fully legalise cannabis for medical and recreational purpose via social movement and public protest (Goñi, U., 2017). Three factors influence the Uruguayan government to legalise cannabis. The first is the Uruguayan government is trying to respond and overcome the problem in domestic security such as the high rate of crime and the perception of insecurity in the society. The second is the Uruguayan government is trying to improve public health in Uruguay, as cannabis can be used for medical purposes including treating Paco users. Also, by legalising cannabis, the Uruguayan government could monitor the quality of cannabis, control the safe dose consumption of cannabis by limiting the plant and sale of cannabis. The third is that the Uruguayan government could reduce its national budget cost to tackle the problem caused by drugs and gain profit from tax revenue of cannabis sales that can be used to educate and develop the state.

The second factor of national interest is changeable and decided by the situation (Kiyono, K., 1969). It was proven by the changing of the policy of the Uruguayan government. Firstly, Uruguay ratified the international drug control conventions in order to support the war on drugs (Walsh, J., \& Ramsey, G. 2016). Before having the Uruguay law no 19172, Uruguayan government has Uruguay law no 14294 (later amended as Uruguay law no 17016). The law was adopted from international drug control conventions. Drug possession for personal use has been decriminalised since 1974 after the Uruguayan government passed the Uruguay law no. 14294, but the law did not give any specific quantity level of cannabis possession for personal consumption that could be sentenced (Faubion, J., 2013).

Then, Law no. 14294 was amended and modified into Law no. 17016, but the law did not define and explain the terms of cannabis as personal consumption (Faubion, J., 2013 pg. 393). Because there is no explanation about the terms of personal consumption, it became the responsibility of the judge to use their authority to determine whether a defendant has marijuana for personal use or the defendant in the purpose of possession to involve in the illegal trafficking. If the judge found that the defendant was guilty, then the defendant would be the subject to criminal repercussions (Faubion, J., 2013 pg. 384). Because there is no clear explanation about the terms, it could lead to injustice. In addition, there is a gap in the law implementation where the personal consumption is protected, but the cultivation of cannabis is prohibited. It was expressed in Uruguay Law no. 17016 that individuals have a right to personal consumption, but is prohibited from cultivation (Transnational Institute., 2015). This condition is difficult to explain and justify; in addition, it will force the users to interact with criminal organisations in order to get cannabis.

However, then the situation changed, the failure of the war on drugs policy in Uruguay triggered national problems (WOLA, TNI \& OSF., 2012). Despite the unclear policy which led to ineffective implementation, at that time, Uruguay also faced domestic security problems such as the high crime rate and the perception 
of insecurity; the high number of Paco users that threaten public health, and the national budget lost that has spent to overcome the problem caused by drugs changed the national interest of Uruguay. Therefore, the worsening condition in Uruguay has changed the perspective of the government towards the compliance of the drugs regime. The Uruguay law no. 17016 that adopted from international drug control convention was considered not effective to solve the problem caused by drugs, and then the Uruguayan government decided to find another alternative way by having Uruguay law No. 19172 about cannabis legalisation in 2013.

\section{Conclusion}

The linkage between all of these factors which led to cannabis legalisation is that international drugs regime which became the foundation of the drugs law in Uruguay has brought more detriments than benefits. Uruguayans have used cannabis for decades and efforts to stop this habit were proven ineffective considering the increasing number of users. Instead, the illegality of cannabis has driven them to seek other alternatives such as the black market, the use of Paco and criminal acts such as killings and robbery. The government saw these as a threat to their national security and interest. Thus, even though Uruguay is a party to International drug control convention and previously comply with it, they finally stood against the conventions by having Uruguay law no.19172 in order to seek for solutions towards their national security problems and to achieve national interests. If the government of Uruguay stands for the international drugs regime, then the casualty from the increasing Paco users and criminals will be hampering the "self-preservation" of Uruguay as a state.

Furthermore, the significant increase of national budget to manage drugs related problem will jeopardise the state's duty on providing welfare to its nations. Therefore, the response coming from INCB stating the disagreement and critics towards the Uruguayan government for violating International Drug Control Conventions could not stop Uruguay to pass the law 19172 on cannabis legalisation. It showed that the changing of state behaviour towards international law is profoundly affected by the factors of national interest.

\section{References}

A Brief History of the Drug War. (n.d.). Retrieved from http://www.drugpolicy.org/issues/brief-history-drug-war

Aron, Raymond. 1981. Peace and War: A Theory of International Politics. Malabar Florida: Krieger Publishing Company. 733

Bewley-Taylor, D., \& Jelsma, M. (2012). Regime change: Re-visiting the 1961 Single Convention on Narcotic Drugs. International Journal of Drug Policy, 23(1), 72-81. doi:10.1016/j.drugpo.2011.08.003 
Behravesh, M. (2010, December 19). Realism and Neorealism: An Investigative Overview. Retrieved from http://www.e-ir.info/2010/12/19/realism-andneorealism-an-investigative-overview/

Boidi, M. F., Cruz, J. M., Queirolo, R., \& Bello-Pardo, E. (2014). Marijuana Legalization in Uruguay and Beyond. Retrieved from https://lacc.fiu.edu/events/2015/marijuana-legalization-in-uruguay-andbeyond/14561_sipa_marijuana-research_report2-1.pdf

Brunnée, Jutta, and Stephen J. Toope (2010). Legitimacy and Legality in International Law: An

Interactional Account. Cambridge, New York: Cambridge University Press

Burgstaller, M. (2005). Theoris of Compliance with International Law (Vol. 52). Leiden, The

Netherlands: Martinus Nijhof Publishers.

Cannabis legalisation in Uruguay: public health and safety over private profit I Transform: Getting Drugs Under Control. (2017, July). Retrieved from http://www.tdpf.org.uk/blog/cannabis-legalisation-uruguay-public-health-andsafety-over-private-profit-0

Cave, D. (2012, July 29). Uruguay Considers Legalizing Marijuana to Stop Traffickers. Retrieved from http://www.nytimes.com/2012/07/30/world/americas/uruguay-considerslegalizing-marijuana-to-stop-traffickers. html

Chimni, B. S. (2017). The Classical Realist Approach to International Law: The World of Hans

Morgenthau. In International law and world order: A critique of contemporary approaches (2nd ed., pp. 38-103). Retrieved from https://doi.org/10.1017/9781107588196.004

Drugs Policy Alliance (DPA) is an organization based in New York that focused on drug policy reform. Drugs Policy Alliances. (n.d.). About Us. Retrieved from http://www.drugpolicy.org/about-us\#vision-mission

Faubion, J. (2013). Reevaluating Drug Policy: Uruguay's Efforts to Reform Marijuana Laws. Law and Business Review of the Americas, 19, 383-408. Retrieved from https://scholar.smu.edu/cgi/viewcontent.cgi?referer=https://www.google.co.id/ \&httpsredir $=1 \&$ article $=1141 \&$ context $=$ lbra 
Garibotto, G. (n.d.). Prisons and drugs in Uruguay. Retrieved from https://www.tni.org/files/publication-downloads/tni-systems_overload-uruguaydef.pdf

Garibotto, G. (n.d.). System Overload: Prisons and drugs in Uruguay. Retrieved from http://druglawreform.info/en/country-information/latinamerica/uruguay/item/874-drug-laws-and-prisons-in-uruguay

Goni, U. (2013, October 22). Uruguay sets price of legalised cannabis at $\$ 1$ a gram. Retrieved from https://www.theguardian.com/world/2013/oct/22/uruguay-legal-cannabis-1dollar-gram

Goñi, U. (2016, March 24). Uruguay's legal marijuana policy en route to next phase of regulation. Retrieved from https://www.theguardian.com/world/2016/mar/24/uruguay-legal-marijuananext-phase-regulation

Goñi, U. (2017, May 27). Uruguay, the first country where you can smoke marijuana wherever you like. Retrieved from https://www.theguardian.com/society/2017/may/27/marijuana-legalisationuruguay-seen-half-measure-users

Government supplied cannabis: Uruguay's controlled high. (2018, January 10). Retrieved from http://www.euronews.com/2018/01/10/government-supplied-cannabis-uruguays-controlled-high

Halter, C. (2016, October 6). Uruguay Reduces Drug War to Increase Public Health. Retrieved from https://www.tusaludmag.com/article/uruguay-legalizesmarijuana-25481-6830

Hetzer, H. (2013, December 11). Opinion: Finally, a nation legalizes pot - CNN. Retrieved from https://edition.cnn.com/2013/12/10/opinion/hetzer-uruguaylegalizes-marijuana/index.html

\& Walsh, J. (2014, June 17). Pioneering Cannabis Regulation in Uruguay. Retrieved from https://nacla.org/article/pioneering-cannabis-regulation-uruguay

Hernandez, V. (2012, November 15). The world's poorest president. Retrieved from http://www.bbc.com/news/magazine-20243493

Holmes, S. (2017, April 7). Uruguay becomes the first country to sell cannabis in pharmacies. 
Retrieved from http://www.dailymail.co.uk/news/article-4388782/Uruguaygives-pharmacies-green-light-start-selling-marijuana.html

Hurtado-Gumucio, J. (2000, October). Coca leaf chewing as therapy for cocaine maintenance. - $\quad$ PubMed - NCBI. Retrieved from https://www.ncbi.nlm.nih.gov/pubmed/11104945

International Narcotics Control Board (INCB). (2016). Report of the International Narcotics Control Board for 2016; Page 29. Retrieved from https://www.incb.org/documents/Publications/AnnualReports/AR2016/English/A R2016_E_ebook.pdf

International Security Sector Advisory Team (ISSAT). (2015, February 13). Uruguay Country Profile - International Security Sector Advisory Team (ISSAT). Retrieved from https://issat.dcaf.ch/Learn/Resource-Library/CountryProfiles/Uruguay-Country-Profile

Jackson, Robert \& Sorensen, G., 1999. Page 89. Introduction to International Relations. Oxford:

Oxford University Press.

Kiyono, K. (1969). A Study on the Concept of the National Interest of Hans J. Morgenthau: As the Standard of American Foreign Policy. Retrieved from http://naosite.lb.nagasaki-

u.ac.jp/dspace/bitstream/10069/27783/1/keieikeizai49_03_04.pdf

Londoño, E. (2017, July 19). Uruguay's Marijuana Law Turns Pharmacists Into Dealers. Retrieved from https://www.nytimes.com/2017/07/19/world/americas/uruguay-legalizes-potmarijuana.html

Madras, B. K. (n.d.). Update of Cannabis and its medical use. Retrieved from http://www.who.int/medicines/access/controlled-

substances/6_2_cannabis_update.pdf

Malanczuk, P., \& Akehurst, M. (1997). Treaty. In Akehurst's modern introduction to international law (7th ed., p. 132).

Marcos.santos. (n.d.). UNODC and the response to drugs. Retrieved from https://www.unodc.org/lpo-brazil/en/drogas/index.html

Ministry of Interior - Ministerio del Interior. (2012). Retrieved from https://www.minterior.gub.uy/index.php/83-observatorio/estadisticas/82estadisticas 
Moreno, R. P. (n.d.). Cannabis in Uruguay: A case study of the regulated cannabis market in
Uruguay.
Retrieved
from
http://www.diva-

portal.se/smash/get/diva2:1069404/FULLTEXT01.pdf

Morgenthau, H. J. (1993). Politics among nations: The struggle for power and peace. New York: McGraw-Hill.

(1949). The Primacy of National Interest. The American Scholar, $18(2), 207-212$.

News, A. (2013, August 15). President of Uruguay: Love "Is the Only Healthy Addiction". Retrieved from http://abcnews.go.com/ABC_Univision/uruguayanpresident-legal-weed-love/story?id $=19972551$

Oliver, J. (2016). Part II Approaches, Ch.16 Realist Approaches to International Law. The Oxford Handbook of the Theory of International Law. doi:10.1093/law/9780198701958.003.0017

Panicker, B. (2015). Legalization of Marijuana and the Conflict with International Drug Control Treaties. Page 6. Retrieved from http://studentorgs. kentlaw.iit.edu/jicl/wpcontent/uploads/sites/5/2016/01/Legalization-of-Marijuana-and-the-Conflictwith-International-Drug-Control-Treaties.pdf

Pascual, A. (2014). Cannabis Legalization In Uruguay. Retrieved from http://www.austriancenter.com/wp-content/uploads/2014/01/Pascual-AlfredoCannabis-legalization-in-Uruguay.pdf

Planas, R. (2014, August 21). Uruguayan Prez Explains Why Legalizing Weed Is A 'Security Issue'. $\quad$ Retrieved from https://www.huffingtonpost.com/2014/08/21/mujica-weed-security_n_5698413.html)

Political Realism in International Relations. (2010, July 20). Retrieved from https://plato.stanford.edu/entries/realism-intl-relations/

Pressly, L. (2014, March 5). Uruguay's battle with 'pasta base'. Retrieved from http://www.bbc.com/news/magazine-26436094

Queirolo, R., Boidi, M. F., \& Cruz, J. M. (2016). Cannabis clubs in Uruguay: The challenges of regulation. International Journal of Drug Policy, 34, 41-48. doi:10.1016/j.drugpo.2016.05.015 
Ramsey, G. (2013, July). Uruguay: Marijuana, Organized Crime, and the Politics of Drugs. Retrieved from https://www.insightcrime.org/images/PDFs/2016/uruguay_legalization.pdf

(2016, November). Getting Regulation Right: Assessing Uruguay's Historic Cannabis Initiative. Retrieved from https://www.wola.org/wpcontent/uploads/2016/09/Getting-Regulation-Right-WOLA-Uruguay.pdf

\& Walsh, J. (2017, May 1). Uruguay is creating the world's first nationwide regulated cannabis market. Retrieved from http://www.druglawreform.info/en/weblog/item/7594-uruguay-is-creating-theworld-s-first-nationwide-regulated-cannabis-market

(2017, July 18). In a Historic Step, Non-Medical Cannabis Sales to Begin in Uruguay. Retrieved from https://www.wola.org/analysis/historic-step-nonmedical-cannabis-sales-begin-uruguay/

Reports and Documents. (n.d.). Retrieved from http://www.infodrogas.gub.uy/index.php?option=com_content\&view=category\&l ayout $=$ blog\&id $=8 \&$ Itemid $=18$

Republica Oriental Del Uruguay Poder Legislativo. (2013, December). Ley 19.172. Retrieved from https://legislativo.parlamento.gub.uy/temporales/leytemp2120905.htm

Shirley V. Scott (1994). International Law as Ideology: Theorizing the Relationship between International Law and International Politics. European Journal International. Retrieved from http://www.ejil.org/pdfs/5/1/1245.pdf

Sledge, M. (2014, April 4). Uruguay Considers Giving Medical Marijuana To Cocaine Addicts. Retrieved from https://www.huffingtonpost.com/2014/04/04/uruguay-medicalmarijuana_n_5092773.html

Thoumi, F. E. (n.d.). The Relationship between Illegal Drugs and Violence: Is There a Cause and

Effect? Retrieved

from

http://lanic.utexas.edu/project/etext/lilas/portal/portal109/drugs.pdf

Transform Drug Policy Foundation. (n.d.). Ending the war on drugs - How to win the global drug

policy debate. Retrieved from http://www.tdpf.org.uk/sites/default/files/GlobalDrug-Policy-Debate_0.pdf 
Transnational Institute. (2003, March). Conventions - UN Drug Conventions Reform. Retrieved from http://www.druglawreform.info/en/un-drugcontrol/conventions/item/2185-un-drug-conventions-reform (2006, October). Paco Under Scrutiny: The cocaine base paste market in Argentina, Uruguay and Brazil. Retrieved from http://www.druglawreform.info/images/stories/documents/debate14.pdf (2014, June 11). Reform proposals and reforms to drug laws. Retrieved from https://www.tni.org/es/node/12323 (2015, June 29). About drug law reform in Uruguay. Retrieved from https://www.tni.org/es/node/22438 United Nation Office on Drugs and Crime (UNODC). (1961). Single Convention on Narcotic Drugs 1961. Article 2 Section 9. Retrieved from https://www.incb.org/documents/Narcotic-Drugs/1961Convention/convention_1961_en.pdf

United Nation Office on Drugs and Crime (UNODC). (1961). Single Convention on Narcotic Drugs 1961. Article 4. Retrieved from https://www.incb.org/documents/Narcotic-Drugs/1961Convention/convention_1961_en.pdf

United Nations. (1969, May 23). Vienna Convention on the law of treaties 1969. Article 11. Retrieved from https://treaties.un.org/doc/publication/unts/volume\%201155/volume-1155-i18232-english.pdf

United Nations. (1969, May 23). Vienna Convention on the law of treaties 1969. Article 12 (1). Retrieved from https://treaties.un.org/doc/publication/unts/volume\%201155/volume-1155-i18232-english.pdf

Uruguay is breaking the International Conventions on Drug Control with the Cannabis Legislation approved by its Congress. (2013, December 11). Retrieved from

https://www.incb.org/documents/Publications/PressRelease/PR2013/press_relea se_111213.pdf

Uruguay Marijuana Legalization Law - English Translation. (2013). Article 9. Retrieved from https://www.drugpolicy.org/sites/default/files/Uruguay_Marijuana_Legalization_ Law_English_Translation.pdf

Uruguay pharmacies start selling cannabis straight to consumers. (2017, July 20). Retrieved from https://www.theguardian.com/world/2017/jul/19/uruguay-marijuana-salepharmacies 
Walsh, J., \& Ramsey, G. (2016). Uruguay's Drug Policy: Major Innovations, Major Challenges. Page 2. Retrieved from https://www.brookings.edu/wpcontent/uploads/2016/07/Walsh-Uruguay-final.pdf

Washington Office on Latin America (WOLA), Transnational Institute (TNI), \& Open Society Foundation (OSF). (2012, June 17). Drugs and Prisons in Uruguay: The Case for a Regulated Marijuana Market [Video file]. Retrieved from https://www.wola.org/analysis/drugs-and-prisons-in-uruguay-the-case-for-aregulated-marijuana-market/

Watts, J. (2013, November 18). Uruguay's likely cannabis law could set tone for war on drugs in

Latin America. Retrieved from https://www.theguardian.com/world/2013/nov/18/uruguay-cannabis-law-waron-drugs-marijuana 